\title{
Efficiency of Indian Commodity Market: A Survey of Brokers' Perception
}

\author{
Shashi Gupta \\ The North Cap University (formerly ITM Unviersity) Gurgaon \\ Himanshu Choudhary \\ The North Cap University (formerly ITM Unviersity) Gurgaon \\ D. R. Aggarwal \\ The North Cap University (formerly ITM Unviersity) Gurgaon
}

\begin{abstract}
The present study documents the finding of a survey of brokers 'perception pertaining to the recently introduced commodity derivatives market in India. The survey results show the brokers' assessment about trading/marketing activities and their perception of the benefits and concerns about commodity derivatives. It also throw some light on the perception of brokers about the efficiency of Indian commodity derivatives in performing the functions of price discovery, hedging effectiveness and volatility dynamics. The survey results show that high net worth individual are contributing significantly in the trade volume of commodity derivatives. Interestingly, retail investors are also emerged as the significant contributor in total turnover of brokers. Survey results exhibit that price discovery and hedging effectiveness functions are well performed by all the commodity futures except the energy commodities futures. Energy commodities, being the most volatile commodities, are perceived as having less hedging effectiveness as compared to others. Brokers are assenting on the high to moderate impact of open interest, volume and time to maturity on the volatility of the commodity futures derivatives.
\end{abstract}

Keywords: Brokers'perception, commodity futures, Price discovery, hedging, volatility Dynamics

\section{INTRODUCTION}

$\mathrm{F}$ inancial market is an indispensable part of the economic development of any country. Derivative security, one of the important constituent of the financial market, derives its value from underlying financial variables such as commodity price, stock price, exchange rate, interest rate, and indices. In the last decade, Indian derivative market has evolved exponentially and reached all across the world since its inception in the year 2000. Although trading in the commodity derivative was rooted in 1875 with the establishment of Bombay Cotton Trade Association Ltd., its formal organized trading in commodities was started in the year 2003 with the recognition of three electronic exchanges as National Commodity Electronic Exchanges namely, Multi Commodity Exchange (MCX), National commodity Derivative Exchange (NCDEX), and National Multi-Commodity Exchange of India (NMCE). Commodity derivative trading has always been a subject of much

Journal of Technology Management for Growing Economies Vol. 7, No. 1 April 2016 pp. 55-71

\section{CHITKARA 司 UNIVERSITY}

C 2016 by Chitkara University. All Rights Reserved. 
Gupta, S.

Choudhary, H.

Aggarwal, D. R.

debate due to increase in inflation and speculation activities (Kindleberger, 1996). Financial Times columnist James Morgan has put the speculation nature of derivative market in the following words, 'A derivative is like a razor. You can use it to shave yourself....or you can use it to commit suicide' ${ }^{1}$. Much of popular discussion about the losses caused by these derivative securities might fade away the profits associated with it. Commodity-linked derivatives are an effective hedging device against fluctuations in price of commodities like energy products, foreign exchange, precious metal (gold, silver), industrial metal (aluminum, steel etc.) and agricultural commodities (rice, jawar, soybeans, wheat etc.) (Kumar et al., 2008). Commodity derivatives aid in the allocation of risk across investors, firms and small producers, and they also lower the costs of diversifying portfolios (Bose, 2007). In India, commodity derivatives are allowed through futures or forward. Option are not allowed to trade in India. Commodity derivatives are considered to perform three main functions namely, risk management, price discovery and hedging. Many researchers has studied the efficiency of Indian commodity derivative market in performing these function empirically. But only few studies have been conducted for analyzing the brokers' perception about efficiency of commodity derivatives. Brokers being an important constituent of derivative market play a significant role in efficient functioning of commodity futures market. It is felt that the inclusion of perception of brokers and investors is extremely important to get the further insight into the derivative market. In the present paper, an endeavor has been made to explore the efficacy of Indian commodity market from the brokers' perspective in performing the function of risk management, price discovery and hedging. This paper is organized as follows: Section 2 addresses the literature review. Sections 3 and 4 elaborate upon the needs and objectives of the study respectively. Section 5 explains the research methodology used in the study. The analysis of perception of brokers about derivative securities is captured in section 6 , which is further subdivided into demographics of brokers, trading and marketing activities of brokers, usage and concern about derivative markets, and price discovery and hedging effectiveness in commodity futures. Section 8 summarizes the conclusion of this study.

\section{LITERATURE REVIEW}

A number of empirical studies have been conducted in the Indian commodity futures market to study its efficiency in term of price discovery, hedging and volatility dynamics. Srinivasan and Ibrahim (2012) studied the price discovery in NCDX and found that both spot and futures market participate in price discovery function as information flow simultaneously in both the market. Sehgal et al.

Journal of Technology Management for Growing Economies, Volume 7, Number 1, April 2016 
(2013) conducted a study in MCX and found the evidence of price discovery in futures market and information flow from futures market to spot market. Price discovery function has been studied by Iyar and Pillai (2010) in Indian commodity market for copper, gold, silver, chickpeas, nickel and rubber. They concluded that in case of copper, gold and silver, rate of convergence of the information is almost instantaneous. However for rest of the commodities, the rate of convergence of information slack during the expiration week. Inoue et al. (2014) has studied the market efficiency of Indian commodity market and found the evidence of weak efficient market for more recent sub sample period since July 2009 onwards. Bose (2007) analyzed the hedging effectiveness of commodity futures (MCX) indices in India and found that the notional commodity indices behave like the equity indices in terms of efficiency and flow of information. It was also confirmed that futures market helps to reduce volatility in the spot prices of the relevant commodities and provide for effective hedging of price risk. Kumar and Singh (2008); Gupta and Rajib (2012) questioned the dynamic relation among trading volume, volatility and price change in Indian commodity market. Both found the positive relationship between volume and volatility. Maitra (2014) studied the impact of volume and open interest on volatility in Indian commodity market. He found that volatility and open interest has positive relationship with volatility.

To the best of our knowledge, there has been only two studies (Srivastava et al., 2008; Gahlot and Datta, 2011) conducted in India to study the brokers' perception about usage, concern and price mechanism of Indian derivative. In the present paper, we have tried to move one step further by conducting a primary study to gauge the perception of brokers about efficiency (price discovery, hedging and volatility dynamics) of commodity futures in India and identify the purposes for which these securities are used.

\section{NEED FOR THE STUDY}

Brokers are working as an important link between commodity exchange, participants and the regulator. Commodity market is a complex area with plethora of fundamentals influencing its price movement. The commodity market consists of corporations, firms, and individual traders. All participants want to have information on the fundamentals specific to trading commodities and converge these information on an efficient trading platform to earn a nominal return. Brokers not only help the investors to take trading decisions but also share the responsibility with the commodity exchanges for the knowledge development and sharing among the participants of the commodity ecosystem. Thus, it becomes imperative to understand the brokers' perception about the market and investors' behavior.
Efficiency of

Indian

Commodity 


\section{Gupta, S. OBJECTIVES OF SURVEY}

Choudhary, H. The present survey is conducted with the main objective of understanding the Aggarwal, D. R. perception of brokers about different aspects of commodity derivatives. The following issues are addressed though the set of questions in the survey:

1) Trading and marking activities of brokers in the commodity derivatives.

2) Different purposes for which the commodity futures are used by the investors.

3) Reasons for non-investment in the commodity futures.

4) Issues concerning the investors to invest in commodity derivatives.

5) Price discovery and hedging effectiveness of commodity futures.

6) Impact of exogenous variables on the volatility dynamics of commodity futures.

\section{METHODOLOGY}

The primary data have been collected from the brokers registered with MCX, working in the region of NCR-Delhi. The questionnaires were sent to 250 brokers online and offline and some questionnaires were administered personally. After repeated persuasion fully filled questionnaires were received from only 95 brokers. This constitutes the 38\% response rate from brokers. The questionnaire used in the survey was prepared by using the established survey research principles and had close ended questions on the above mentioned issues. The questionnaire was based on funnel sequence method which results in sequencing the questions from most general to most specific questions. A pilot study was conducted with a group of 10 people involving academicians, industry experts and brokers along with vigorous validation exercise that included face validity, criterion validity, content validity and construct validity. The suggestions given by these experts were included in the final questionnaire. The data collected from these questionnaires was further analyzed by using Statistical Package for Social Sciences (SPSS 16.0) and Microsoft Excel 2007. The analysis includes frequency distribution, diagrammatic presentation, measure of central tendency and Chi Square test tor testing significant difference between the perception of brokers about price discovery and hedging effectiveness.

\section{ANALYSIS OF RESPONDENT BROKERS' RESPONSE}

\section{Demographics of Respondent Brokers:}

From demographic information, it is found that $73 \%$ of the respondent brokers belonged to the age group of 20-29 and $27 \%$ respondent belonged to the age group of 30-49. On the basis of experience, $73 \%$ respondent had less than 10 years of 
experience while $27 \%$ respondent had more than 10 years of experience. On the basis of gender, a majority of respondents (86\%) were male and a meagre $13 \%$ of total respondents were female. It seems that broking business is taken up very enthusiastically by young males with less experience. The possible reason could be the more risk appetite in young people and tough job environment discourage old people. Electronic trading may be another reason as old people generally do not feel themselves fit in the digital environment.

\section{Trading/Marketing Activity in Commodity Futures}

One set of questions in the survey was related to the respondent brokers' activities in the market. Information related to turnover, classification of trading volume, marketing efforts and clientele etc. was collected from these questions. The survey results are reported in the further sub-sections.

\section{Membership Category of Brokers in Commodity Futures}

Every organized market whether cash or derivative, work through the members spread all across the country. For efficient trading of the commodity futures, exchanges are working through registered members who are categorized in to four segments, namely: a) Trading-cum-clearing member (TCM ${ }^{2}$ b) Institutional trading-cum-clearing member $(\mathrm{ITCM})^{3} \mathrm{c}$ ) Professional clearing member $(\mathrm{PCM})^{4}$, and d) Trading member (TM) . Figure 1 shows the details of the categorization of the respondents. The maximum respondents of the study belong to the category of trading-members $(47 \%)$ while the representation from professional clearing member category is the least (2\%). The reason for such a low representation is that very few members are registered in this category. As on $31^{\text {st }}$ March 2013, only 4 members were registered with MCX as professional clearing member.

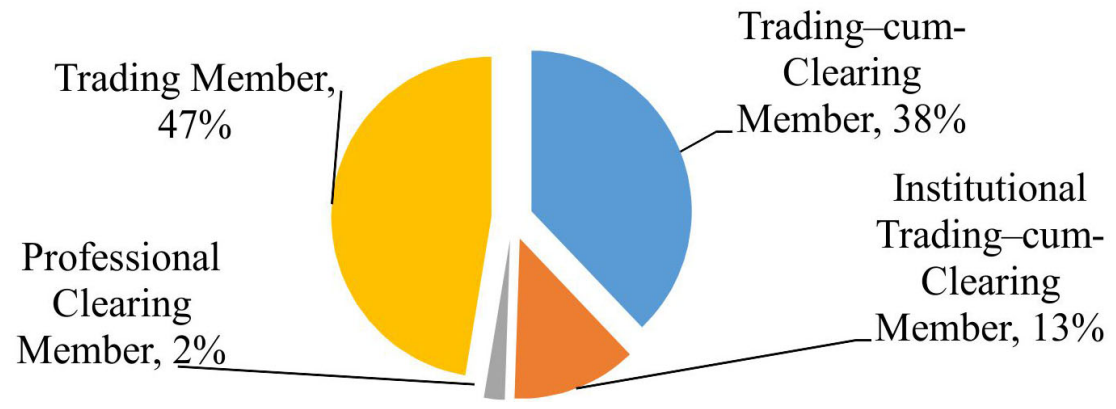

Figure 1: Categorization of respondents

\section{Turnover Analysis}

Respondent brokers were asked the details of the average daily turnover in the commodity futures. It was made clear to respondents that average daily

Journal of Technology Management for Growing Economies, Volume 7, Number 1, April 2016 
Gupta, S.

Choudhary, H.

Aggarwal, D. R. turnover means the notional value of contracts. The percentage of respondents against the distribution of turnover is exhibited in Figure 2.

As shown in Figure 2, 84\% of respondent brokers had a total turnover between 25 crore to 50 crore and $13 \%$ brokers traded in $5-25$ crore segment. A further questioning with brokers revealed that the major proportion of their turnover (53\%) was contributed by the client based trading and rest $(47 \%)$ was contributed by the proprietary trading. This survey simply gives insight that the brokers are more inclined towards the client based trading. The reason for such inclination is simple as in the proprietary trading the risk bearer is the broker but in client trading the risk bearer is client. Restrictions imposed by the exchanges on proprietary trading may be another major reason for such a low participation.

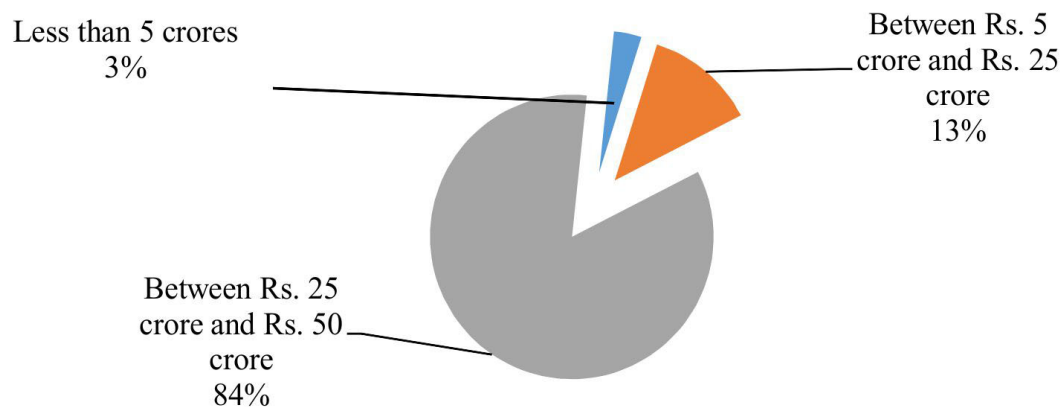

Figure 2: Average daily turnover of brokers in commodity futures

\section{Categories of Commodity Derivatives}

There are majorly four categories of commodity derivatives in which the brokers trade, namely, Commodity futures indices, Futures on agricultural commodities, Futures on metal commodities and Futures on energy commodities. All respondents of the study deal in all types of commodity futures. Figure 3 exhibits that maximum trading is done in commodity futures indices as these are contributing more than $50 \%$ of turnover among $35 \%$ respondents.

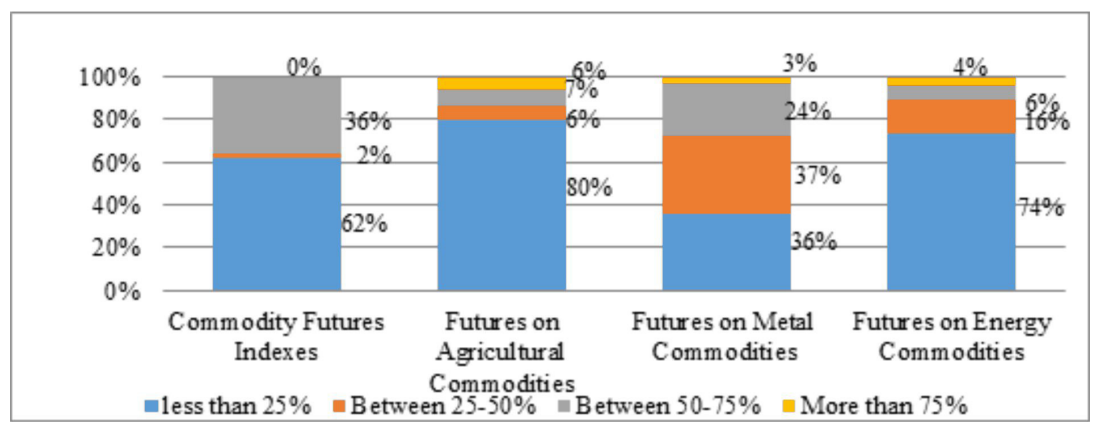

Figure 3: Percentage of a Specific Derivative Security in Total Turnover 
The plausible reason for popularity of commodity futures indices may be the removal of fear of physical deliveries, which is a general worry among the investors. Besides, it also ensures better returns with a moderate risk. Goldman Sachs reported that globally total investment in commodity derivatives is about $\$ 80$ billion out of which 60 per cent i.e. $\$ 48$ billion are invested into passive index-tracking instruments (Shunmugam and Praveen, 2007). Futures on agricultural and energy commodities are not found to be popular as demonstrated by the Figure 3. More than $70 \%$ of the respondents had less than $25 \%$ of the total turnover contributed by these securities. The reason for less popularity of these securities may be high government intervention in these securities which does not allow these futures to react upon market forces. Government interventions interrupt the market fundaments and introduce an unpredictable market factor. These interventions in the futures markets ultimately harm the trust of market players including farmers, hedgers, traders and warehousemen (Hathway, 2007). Since less volatility is found in agricultural commodity futures, speculators are not inclined for investment in these avenues.

\section{Investors' Profile}

The clientele of the respondent brokers was divided into 4 broad categories: high net worth individuals, retail investors, corporate clients, and proprietary trading. Table 1 depicts the information related to the contribution of each category of investors in the total turnover. At the higher end, 19 brokers mentioned that contribution of proprietary trading in total turnover was more than $50 \%$. While for 46 respondent brokers replied that propriety trading contributed less than $25 \%$. Thus, $20 \%$ of the survey participants had more than half of their turnover contributed by the proprietary trading.

High net worth individual has been identified as an important category of investors from the study. They contributed to more than $50 \%$ trading turnover for 51 respondent brokers. While for 36 respondents, $25 \%$ trading turnover had been contributed by high net worth individuals. Interestingly, Retail investors had significant representation in the total turnover. For 14 respondent brokers the contribution of retail investors was more than $50 \%$. This finding is very important and in contradiction to the popular belief that retail investors are not active investors in derivative market because of complexities involved in its valuation. This result also support the constant demand of market participants for reduction in the lot-size of commodity futures which will further induce the investment from the small investors.

Contribution of the corporate clients had been less than $25 \%$ for 49 brokers and it lay between $25-50 \%$ for 26 brokers which exhibit that corporate clients have less participation in commodity derivatives.

Journal of Technology Management for Growing Economies, Volume 7, Number 1, April 2016 
Gupta, S.

Choudhary, H.

Aggarwal, D. R.
Table:1 Investors contribution in turnover of commodity derivatives

(Total no of brokers: 95)

\begin{tabular}{|l|c|c|c|c|}
\hline Categories of client & $\begin{array}{c}\text { Less than } \\
\mathbf{2 5 \%}\end{array}$ & $\begin{array}{c}\text { Between } \\
\mathbf{2 5 - 5 0 \%}\end{array}$ & $\begin{array}{c}\text { Between } \\
\mathbf{5 0 - 7 0 \%}\end{array}$ & $\begin{array}{c}\text { More than } \\
\mathbf{7 5 \%}\end{array}$ \\
\hline $\begin{array}{l}\text { High Net worth } \\
\text { Individuals }\end{array}$ & 36 & 8 & 49 & 2 \\
\hline Retail Investors & 56 & 25 & 10 & 4 \\
\hline Corporate Clients & 49 & 26 & 7 & 0 \\
\hline Proprietary Trading & 46 & 30 & 12 & 7 \\
\hline
\end{tabular}

Source: Authors'calculations

Professional clearing member are not actually engaged in the trading of commodity derivative, besides they support the other members in their clearing and settling the trade. Thus, further analysis is done with two categories of brokers namely, trading members and trading and clearing members as majority of respondent belong to this category $(85 \%)$ and the type of clientele.

Table: 2 Contribution of clients to more than $25 \%$ of turnover

\begin{tabular}{|l|l|l|l|l|}
\hline & $\begin{array}{c}\text { High Net } \\
\text { worth Individ- } \\
\text { uals }\end{array}$ & $\begin{array}{c}\text { Retail } \\
\text { Investors }\end{array}$ & $\begin{array}{c}\text { Corporate } \\
\text { Clients }\end{array}$ & $\begin{array}{c}\text { Proprietary } \\
\text { trading }\end{array}$ \\
\hline Trading Members & 85 & 19 & 15 & 72 \\
\hline $\begin{array}{l}\text { Trading cum Clearing } \\
\text { Members }\end{array}$ & 65 & 15 & 10 & 70 \\
\hline
\end{tabular}

Source: Authors'calculations

Results of Table 2 clearly show the dominance of high net worth individual and proprietary trading in the turnover of these brokers. Retail investors and corporate clients contributed to more than $25 \%$ of turnover for 34 and 25 brokers respectively.

\section{Marketing activities of Brokers}

Traditionally, broking firms were not supposed to engage in the marketing efforts. Survey results exhibit that now a days, because of fierce competition, brokerage firms are inclined toward marketing of their brokering activities.

Journal of Technology Management for Growing Economies, Volume 7, Number 1, April 2016 
Table 3: Marketing activities of brokers under different categories

(brokers' percentage)

\begin{tabular}{|l|c|c|}
\hline Membership & $\begin{array}{c}\text { Active mar- } \\
\text { keting }\end{array}$ & $\begin{array}{c}\text { Existing Cli- } \\
\text { ent Initiation }\end{array}$ \\
\hline Trading Members (TM) & $47 \%$ & $47 \%$ \\
\hline Trading cum Clearing Members (TCM) & $37 \%$ & $4 \%$ \\
\hline Institutional Trading cum Clearing Members (ITCM) & $13 \%$ & $0 \%$ \\
\hline Professional Clearing Members (PCM) & $2 \%$ & $0 \%$ \\
\hline
\end{tabular}

Source: Authors'calculations

Table 3 shows that trading members were more active in marketing strategies and resorted to both the means; active marketing and existing client initiation. $37 \%$ of brokers who are working in the capacity of TCM inclined toward active marketing of their services to clients. Brokers who are working in the capacity of ITCM and PCM, resorted to active marketing and not dependent on client initiation. Currently, due to stiff competition in financial market, every broker is trying to acquire high net worth client and work on the low margin and high volume business model. Active marketing is considered an effective way to increase their volume.

\section{BROKERS' PERCEPTION ABOUT BENEFITS AND CONCERNS OF COMMODITY DERIVATIVES}

Some questions in the survey were related to the respondent's perception of derivative securities which provided information about perceived usage of commodity futures and concerns for not using them.

\section{Usage of commodity derivative securities}

There may be several reasons for which commodity derivatives are used by the investors. Respondent brokers were asked to rank the possible purposes for which they or their clients are using commodity derivatives. We have summarized their responses and calculated the weighted average of the ranks given by the respondents. The result is summarized in the Table 4. 
Gupta, S.

Choudhary, H.

Aggarwal, D. R.
Table 4: Rank of purposes for which client invests in commodity futures

\begin{tabular}{|l|c|c|}
\hline \multicolumn{1}{c}{$\begin{array}{c}\text { Benefits of Derivative } \\
\text { Securities }\end{array}$} & Rank & S.D \\
\hline Hedging & 1 & 0.102598 \\
\hline Price Discovery & 2 & 0.502519 \\
\hline Speculation & 3 & 0.2324 \\
\hline Profit making & 4 & 1.005038 \\
\hline Improving Liquidity & 5 & 0.855156 \\
\hline
\end{tabular}

Source: Authors'calculations

As per the ranks given by the respondent brokers, hedging was the most important purpose as having the highest rank and the least standard deviation (0.102). Improving liquidity was the least important purpose as having the lowest rank with high standard deviation (0.8551). Hedging is considered to be the most important objective for which clients entered into derivative market (Gahlot and Datta, 2011). Interestingly, speculation was considered as the third important purpose of using commodity derivatives by brokers. Speculation activity should not be viewed as the negative outcome of the derivatives because speculation is one of the necessary activities in financial markets. Participants of futures market can be categorized as hedgers or speculators. In case of market crash, it is speculators who remain on the buyer side and become counter party for the hedgers. If speculators pose a threat to the stability of the market on one hand, they also provide liquidity to the market on the other. Similar results are also found by Anand and Kaushik (2008) in the foreign currency derivatives of India. Redistribution of risk is an important financial benefit provided by derivatives products by diverting the risk from risk-averse investors towards those who are more willing and able to bear risk (Alagu Pandian, 2013). Respondent brokers had given second rank to the price discovery which also indicated the efficiency of commodity futures in price discovery function.

\section{Reason for Non-Investment in Commodity Derivatives}

The survey questionnaire included questions related to the reasons for nonusage of commodity derivatives by investors. Brokers have given the ranks to each available option. For analysis purpose, weighted average of given ranks is calculated for each option. It has emerged from the results of Table 5 that insufficient exposure to commodity market and lack of understanding

Journal of Technology Management for Growing Economies, Volume 7, Number 1, April 2016 
of commodity derivatives are the major reasons for non-investment. It is

Efficiency of understandable as the commodity market is barely 10 years old and investors are not aware of its importance and working techniques. Less popularity of Indian commodity market is ranked $3^{\text {rd }}$ as the reason for non-investment. It is the tendency among the investors that they look for the safer investment avenues that is why $4^{\text {th }}$ rank is assigned to 'the inclination toward government securities'. Investors are less interested in investing in commodity derivatives because of complexities involved in their pricing and valuation. In the survey conducted by Srivastava et al., (2008), 69 per cent investors had considered complexities in pricing and valuation to be matter of moderate to high concern. $7^{\text {th }}$ Rank is assigned to the negative perception of investors and the public at large about commodity futures. The big scams in commodity derivatives, such as 500 crore scam of NSE, are portraying a bad picture of commodity market for investors in India.

Table 5:Reasons for non-investment in commodity derivatives

\begin{tabular}{|l|c|c|}
\hline Reasons for not investing in commodity futures & $\begin{array}{c}\text { Weighted } \\
\text { average }\end{array}$ & Rank \\
\hline Lack of understanding of commodity market & 3.484 & 2 \\
\hline Insufficient exposure to Commodity market & 3.095 & 1 \\
\hline Commodity market is not as popular as stock market & 4.105 & 3 \\
\hline People are more inclined toward government securities & 5.179 & 4 \\
\hline Difficulty in pricing and valuing Commodity Futures & 5.632 & 5 \\
\hline Accounting treatment & 5.957 & 6 \\
\hline $\begin{array}{l}\text { Negative perception of investors and the public at large about } \\
\text { Futures }\end{array}$ & 6.579 & 7 \\
\hline $\begin{array}{l}\text { Cost of establishing and maintaining a Futures } \\
\text { exposure exceed the expected benefits }\end{array}$ & 7.747 & 8 \\
\hline Low liquidity in Commodity market & 9.630 & 9 \\
\hline Regulatory hurdles & 9.640 & 10 \\
\hline
\end{tabular}

Source: Authors' calculations

Cost of establishing and maintaining a Futures exposure exceeds the expected benefits, Low liquidity in Commodity market, Regulatory hurdles are the other reasons for non-investment among investors which were assigned as rank $8^{\text {th }}, 9^{\text {th }}$ and $10^{\text {th }}$ respectively. 
Gupta, S.

Choudhary, H.

Aggarwal, D. R.

66

\section{BROKERS' PERCEPTION ABOUT PRICE DISCOVERY, HEDGING EFFECTIVENESS AND VOLATILITY DYNAMICS:}

Commodity derivatives are considered for three main benefits associated with them i.e. risk management, price discovery and hedging. In the present survey an effort has been made to analyze the brokers' perception about these benefits of commodity derivatives.

\section{Price Discovery}

Price discovery function is defined as flow of market information from one market to other market. On the issue of price discovery of underlying assets in the commodity futures, we received a mixed response from brokers. Table 6 shows that maximum $75 \%$ respondents perceived that direction of flow of information is from futures to spot for Futures on metal commodities. 58\% respondents were of view that flow of information is from futures to spot in case of Commodity futures Indices. 50\% respondents believed that it is futures market wherein the market information reflected first in case of Futures on agricultural commodities and energy commodities. A significant number of brokers perceived the flow of information simultaneously in both the market. The Chi square test is applied to see whether there is significant difference between the perceptions of brokers under different derivative securities regarding flow of information. The result was found to be significant, which indicates that there is a significant relationship between type of Derivative Securities and the direction of flow of information. Empirical studies conducted by Acharya et al. (2009) and Aggrwal, et al. (2014) also support the above findings.

Table 6: Price discovery of commodity derivative securities

\begin{tabular}{|l|c|c|c|}
\hline Derivative Securities & $\begin{array}{c}\text { Spot to } \\
\text { Futures }\end{array}$ & $\begin{array}{c}\text { Futures } \\
\text { to Spot }\end{array}$ & $\begin{array}{c}\text { Simultaneously } \\
\text { in both }\end{array}$ \\
\hline a) Commodity Futures Indices & 1 & 55 & 39 \\
\hline b) Futures on Agricultural Commodities & 3 & 49 & 43 \\
\hline $\begin{array}{c}\text { c) Futures on Metal Commodities } \\
\text { (Including Bullions) }\end{array}$ & 0 & 71 & 24 \\
\hline d) Futures on Energy Commodities & 0 & 49 & 46 \\
\hline
\end{tabular}

Chi Square $=13.16$ (Significant)

Source: Authors'calculations

\section{Hedging Effectiveness}

Hedging is considered to be an important motive for using commodity derivatives. We have asked respondents to categorize the commodity futures

Journal of Technology Management for Growing Economies, Volume 7, Number 1, April 2016 
on the basis of their effectiveness in providing hedge against volatility in future spot price. Table 7 shows that all the categories of commodity derivative futures were perceived as being effective for hedging. Maximum $78 \%$ respondents were of view that futures on metal commodities were very effective. 54\% respondent considered Commodity futures indices as effective hedging option. Futures on energy commodities were perceived as very effective by only $29 \%$ brokers. The reason for this less confidence in hedging efficiency of the energy futures may be the volatile nature of this commodity as the prices of these commodities are affected by the domestic as well as global information. Chi square test was applied to find out whether there is significant difference between perceptions of brokers under different derivative securities hedging effectiveness. A significant result was found which indicates that there is a significant relationship between derivative securities and hedging effectiveness.

Table 7: Hedging effectiveness of Derivative securities

\begin{tabular}{|l|c|c|c|}
\hline Derivative Securities & $\begin{array}{c}\text { Very Ef- } \\
\text { fective }\end{array}$ & $\begin{array}{c}\text { Moderately } \\
\text { Effective }\end{array}$ & $\begin{array}{c}\text { Not ef- } \\
\text { fective }\end{array}$ \\
\hline a) Commodity Futures Indices & 54 & 39 & 2 \\
\hline b) Futures on Agricultural commodities & 53 & 40 & 2 \\
\hline $\begin{array}{l}\text { c) Futures on Metal commodities (including } \\
\text { Bullions) }\end{array}$ & 78 & 13 & 4 \\
\hline d) Futures on Energy commodities & 29 & 62 & 4 \\
\hline
\end{tabular}

Chi square 54.29 (Significant)

Source: Authors'calculations

\section{Volatility Dynamics}

In the survey, respondent brokers were asked about the presence of stylized facts of volatility in commodity derivatives. More than $95 \%$ brokers perceived the presence of volatility clustering in futures on metal commodities and futures on energy commodities whereas more than $68 \%$ brokers perceived the existence of volatility clustering in Commodity futures indices and Futures on agricultural commodities. All the brokers unanimously agreed on the existence of feature of mean reversion in volatility for all the commodities futures. In our analysis it has been found that almost all the brokers were of the view that leverage effect is common to all the commodity futures. In the agricultural futures, $30 \%$ brokers were against the presence of leverage effect. Agricultural market is more of Government regulated market so there is not much impact of any positive and negative news. Few empirical studies conducted by Kumar\&

Journal of Technology Management for Growing Economies, Volume 7, Number 1, April 2016
Efficiency of

Indian

Commodity 
Gupta, S. Choudhary, H. Aggarwal, D. R.
Singh (2008) and Gupta et al. (2015) in Indian commodity market have found the presence of volatility clustering and asymmetric properties.

Respondent brokers were also questioned about the impact of exogenous variable on volatility dynamics. More than $95 \%$ brokers perceived there is moderate to high impact of exogenous factors viz., open interest and volume on the volatility of commodities futures. Chi Square test was applied to find out whether there is significant difference between perceptions of brokers under different commodities futures for impact of exogenous factors on volatility. The result was not found to be significant which indicates that there is a no significant relationship between commodities futures and impact of exogenous variables on volatility.

When brokers were also asked about the relationship between time to maturity and volatility of commodity futures, almost all the brokers perceived there is moderate to high impact of time to maturity and volatility of commodity futures. Significant value of Chi Square test also confirmed that there is significant relationship between impact of time to maturity and commodities futures. The brokers' perception is found to be in contradiction with the empirical results. Empirical studies found no time to maturity impact on volatility in Indian commodity futures market (Pati and Kumar, 2006).

\section{CONCLUSION}

This paper exhibits the findings of a survey conducted to analyze the Indian commodity market from the perspective of brokers. The survey was carried on a sample of brokers who are active market participants in the derivative segment of MCX. The survey was focused on the following key issues: a) trading/marketing activities in commodity derivative b) brokers' perception of usage and concern of investment in commodity derivative securities c) price discovery and hedging effectiveness of commodity derivatives d) volatility dynamics of commodity derivatives. The findings of the survey present an overall view of some important issues associated with commodity derivative trading.

The findings of survey present a mixed picture. Some respondents characterize the Indian market as naïve while the others indicate the contrary. Results show that high net worth individuals and proprietary trading are contributing to the major proportion of trading volume in commodity futures. Interestingly, retail investors are having a strong representation in commodity derivative market despite the fact that commodity futures are considered largely beyond their reach because of the complex behavior of market and the relatively high initial investment. The survey results have supported the need of some important policy changes for the derivative market. For example,

Journal of Technology Management for Growing Economies, Volume 7, Number 1, April 2016 
there is a need to bring in more institutional participation by removing the ban on trading activities of FII and investment Banks in Indian commodity market which will help to bring more liquidity and best practices in commodity derivative. Absence of clarity on tax and accounting treatment, and complex internal approval of processes may be the other reasons which discourage FII from investing in commodity market. Roy (2006) suggested the introduction of banks in commodity futures because financing by banks could provide efficient hedge against price risk. There are many barriers imposed in commodity derivative market like: restriction on free movement of commodities in the form of physical restrictions (under the Essential Commodities Act, APMC Act, Licensing restrictions) and fiscal hurdles (differential taxes, stamp duties). The survey also revealed that derivative securities have definitely penetrated into the Indian capital market and investors are using these securities for different purposes, namely, profit enhancement, speculation, hedging and arbitrage. The survey findings support the need to initiate option trading in commodity segment which may prove to be a useful medium for enhancing retail participation.

The Survey results exhibit that price discovery and hedging effectiveness functions are well performed by all the commodity futures except the energy commodities futures, being the most volatile commodity it is perceived as less effective in hedging function. Brokers are assenting on the high to moderate impact of open interest, volume and time to maturity on the volatility of the commodity futures derivatives.

The survey results point out that the trading is concentrated in few hands. The utility of derivative securities needs to be signaled to every nick and corner. The regulator, FMC and the commodity exchanges need to take due cognizance of this fact and do some policy initiatives to improve the functioning of market.

\section{LIMITATION AND SCOPE FOR FURTHER RESEARCH:}

The following are the limitations of the study:

1) The respondent of survey belonged to Delhi-NCR region. The results might vary if the same study is carried out with the brokers' representation from all over the India.

2) Sample size is limited to 95 brokers, because of small sample size results may not be generalized to whole country's brokers.

3) Brokers remain busy with their business as their job is much demanding. It is quite possible that the responses they have given are not after much thought. However, researcher tried her best to get the genuine response by explaining them the importance of the research.

Journal of Technology Management for Growing Economies, Volume 7, Number 1, April 2016
Efficiency of

Indian

Commodity 
Gupta, S.

Choudhary, H.

Aggarwal, D. R.

\section{NOTES}

1. Trading-cum-Clearing Member (TCM) as the registered member of Exchange is entitled to trade on behalf of their own account or their clients and also entitle to clear and settle all such trade done by them.

2. Institutional Trading-cum-Clearing Member (ITCM) has all the rights and responsibilities as TCM, and entitled to settle and clear the trades/transactions done by the Members affiliated with it viz. TCMs or TMs

3. Professional Clearing Member (PCM) are not trading members. They act as a clearing house for Trading members and Institutional trading members.

4. Trading Members (TM) may trade on the Exchange on their own account as well as on account of clients registered with them but they have no right to clear and settle such trades themselves. So they get affiliated with any one of PCM/ITCM for clearing their trades/ transaction.

\section{REFERENCES}

Morgan, J. (1995, May 4) 'Article on derivative market', Financial Times.

Acharya, V. V., Brenner, M., Engle, R., Lynch, A., \& Richardson, M. (2009) 'Derivatives-The ultimate financial innovation', Financial Markets, Institutions \& Instruments, 18:2, pp. 166-167.

Aggarwal, N., Jain, S., \& Thomas, S. (2014) 'Do futures markets help in price discovery and risk management for commodities in India?', Working paper No. 2014-020. Indira Gandhi Institute of Development Research, Mumbai, India.

Alagu Pandian, V. (2013) 'A Study of Investors Preference towards Various Investments Avenues in Dehradun District', International Journal of Management and Social Sciences Research, 4:1, pp.58-66.

Anand, M., and Kaushik, K.P. (2008) 'Management Motivations for Use of Foreign Currency Derivatives in India', IIMB Management Review, 20:3, pp. 324-339.

Bose, S. (2007) 'Commodity Futures Market in India: A Study of Trends in the Notional Multi-Commodity Indices', Money \& Finance, ICRA Bulletin, 3:3, pp. 125-158.

Gupta, S., Choudhary, H., \& Aggarwal, D. R. (2015) 'Volatility Characteristics of Indian Commodity Futures: An Empirical Analysis of MCX Indices', Asian Journal of Research in Banking and Finance, 5:9, pp. 27-43. http://dx.doi.org/10.5958/2249-7323.2015.00113.3.

Gupta, K.S., and Rajib. P. (2012) 'Samuelson Hypothesis \& Indian Commodity Derivatives Market', Asia-Pacific Financial Markets, 19:4, pp. 331-352.

Gahlot, R., \& Datta, S. K. (2011) 'Views of Brokers on Derivatives Trading in India: Issues and Challenges', International Journal of Financial Management, 1:4, pp. 53.

Hathway, K. (2007) 'The Potential Effects of Government Intervention in a Market Economy" Report submitted by Financial Markets International of Washington, DC, and Mumbai, India, April 2007,

Inoue, T., \& Hamori, S. (2014) 'Market efficiency of commodity futures in India', Applied Economics Letters, 21:8, pp. 522-527.

Iyer, V. and Pillai, A. (2010) 'Price discovery and convergence in the Indian commodities market', Indian Growth and Development Review, 3:1, pp. 53-61. http://dx.doi. org/10.1108/17538251011035873.

Kindleberger, Charles P. (1996) 'Manias, Panics and Crashes - History of Financial Crises', John Wiley and Sons.

Kumar, B., \& Singh, P. (2008) 'Volatility modeling, seasonality and risk-return relationship in GARCH-in-mean framework: the case of Indian stock and commodity markets', In The 5th Conference of Asia-Pacific Association of Derivatives Paper.

Kumar, B., Singh, P. \& Pandey, A. (2008) 'Hedging effectiveness of constant and time varying hedge ratio in Indian stock and commodity futures markets', IIMA Working Paper No.

Journal of Technology Management for Growing Economies, Volume 7, Number 1, April 2016 
2008-06-01, pp. 1-35. http://dx.doi.org/10.2139/ssrn.1206555.

Maitra, D. (2014) 'Do volume and open interest explain volatility?: An inquiry into the Indian commodity markets', Journal of Financial Economic Policy, 6:3, pp. 226 - 243.

Pati, P. C. (2006) 'Maturity and volume effects on the volatility: Evidences from NSE fifty futures', In 10th Capital Markets Conference, Indian Institute of Capital Markets Paper.

Roy, Ashutosh (2006), Indian Agri Commodity Market, Risk Management and its Sustainable Growth: An Integrated Framework, Online available on: http://ssrn.com/abstract=1178702.

Sehgal, S., Rajput, N., \& Deisting, F. (2013) 'Price discovery and volatility spillover: Evidence from Indian commodity markets', The International Journal of Business and Finance Research, 7:3, pp. 57-75.

Shunmugam, V., \& Praveen, G.D. (2007, January 4). The index of commodity futures investing. Business Line. The Hindu. Retrived from http://www.thehindubusinessline.com/todays-paper/tp-opinion/the-index-of-commodity-futures-investing/article1645503.ece.

Srivastava, S., Yadav S. S., and Jain, P. K. (2008) 'Derivative trading in Indian stock market brokers perception', IIMB Management Review, 20:3, pp. 311-323.

Srinivasan, P., \& Ibrahim, P. (2012) 'Price Discovery and Asymmetric Volatility Spillovers in Indian Spot-Futures Gold Markets', International Journal of Economic Sciences and Applied Research, 3:1, pp. 65-80.

Ms. Shashi Gupta, Research Scholar, The North Cap University (formerly ITM University), Gurgaon. Email: shashigupta085@gmail.com.

Mr. Himanshu Choudhary, Associate Professor, The North Cap University (formerly ITM University) Gurgaon. Email: dr.himanshu.c@gmail.com.

Prof. D.R. Agarwal, Professor of Emeritus, The North Cap University (formerly ITM University) Gurgaon. Email: dragarwal@itmindia.edu. 